\title{
DENITRIFYING WOODCHIP BIOREACTOR LEACHATE TANNIC ACID AND TRUE COLOR: LAB AND FIELD STUDIES
}

\author{
N. M. Wickramarathne, R. A. Cooke, R. Book, L. E. Christianson
}

\section{HighLIGHTS}

- Oak leached more tannic acid, true color, and chemical oxygen demand (COD) than ash and mixed hardwood chips.

- The factors became similar (tannic acid, COD) or below stream levels (true color) after flushing.

- Eleven site-years of field bioreactor data showed decreasing tannic acid and true color over time.

- Post-startup tannic acid was lower in bioreactor outflow than in area streams.

- True color did not appear to be a reliable indicator of leachate tannic acid at low concentrations.

ABSTRACT. Woodchips have been a preferred denitrifying bioreactor medium to date, but concerns about potential harmful effects of tannins in the leachate have precluded the use of oak chips in many installations. A study was conducted to compare the suitability of oak (genus Quercus) woodchips as a denitrifying bioreactor medium relative to other types of woodchips, both in lab leachate tests and in the context of observed bioreactor leaching in the field. Assessment measures included the content of tannic acid and other compounds in the leachate, as well as leachate color, which can often be high during startup. An 84-day leaching test using rectangular bioreactor cells filled with either oak (Quercus rubra), ash (Fraxinus spp. L.), or a generic hardwood blend showed that oak initially leached higher concentrations of tannic acid, true color, and chemical oxygen demand (COD) than the other two media. The significant differences in leached concentrations among the three wood types were eliminated after a finite leaching period. Tannic acid and true color in 11 site-years of field bioreactor outflow data generally decreased over time, except following a dry period when one of the bioreactors received no drainage inflow for more than two months. The lab and field results indicated the capability of woodchip bioreactors to flush at least these two analytes to ambient stream levels. True color did not appear to be the best parameter for estimating the tannin content of woodchip leachate due to discrepancies at low concentrations. Mass normalized tannic acid leaching ranged from 0.03 to approximately $40 \mathrm{mg}$ tannic acid $\mathrm{g}^{-1}$ woodchip across the lab and field assessments. Oak initially leached more tannic acid, color, and COD than the other wood types, but the eventual similarity among the wood types after flushing with a sufficient number of pore volumes meant that any potentially negative environmental impacts would likely be limited to the startup period or possibly after dry periods. Oak initially eluted higher mean total nitrogen (TN) concentrations than the other wood types, but the treatments were not significantly different by day 3, indicating that biological $N$ removal was not significantly inhibited, even with high concentrations of tannic acid.

Keywords. Chemical oxygen demand, Oak, Tannin, Water quality, Wood leachate.

(c) (1) (5) $\Theta$ The authors have paid for open access for this article. This (c) ${ }_{\mathrm{BY}} \mathrm{NC}$ ND work is licensed under a Creative Commons AttributionNonCommercial-NoDerivatives 4.0 International License https://creative commons.org/licenses/by-nc-nd/4.0/

Submitted for review on 25 March 2020 as manuscript number NRES 14020; approved for publication as a Research Article by the Natural Resources \& Environmental Systems Community of ASABE on 24 July 2020.

The authors are Niranga M. Wickramarathne, Graduate Student, Department of Crop Sciences, and Richard A. Cooke, Professor, Department of Agricultural and Biological Engineering, University of Illinois, Urbana, Illinois; Ruth Book, State Conservation Engineer, USDANRCS Illinois State Office, Champaign, Illinois; Laura E. Christianson, Assistant Professor, Department of Crop Sciences, University of Illinois, Urbana, Illinois. Corresponding author: Laura Christianson, AW-101 Turner Hall, 1102 South Goodwin Ave., Urbana, IL 61801; phone: $217-$ 244-6173; e-mail: lechris@illinois.edu.
$\mathrm{T}$ The denitrifying bioreactor is a conservation practice typically implemented at the edge-of-field for longterm $\left(\sim 10\right.$ years) nitrate-nitrogen $\left(\mathrm{NO}_{3}-\mathrm{N}\right)$ removal from agricultural drainage water. Woodchips are the most commonly used medium in this type of denitrifying bioreactor because of their high carbon to nitrogen $(\mathrm{C}: \mathrm{N})$ ratios, low cost, local availability, high permeability, and longevity as a carbon source (Christianson et al., 2012; Schipper et al., 2010). However, naturally occurring wood constituents and decomposition by-products are present in wood leachate, which could cause an environmental concern. The chemical composition and associated potential toxicity of wood leachate varies with tree species, tree component (bark, heartwood, sapwood, or foliage), leaching time and throughput volume, and characteristics of the leaching water (e.g., pH; Fernández de Simón et al., 2010; Hedmark and Scholz, 2008). 
Plants produce thousands of phenols, of which tannins are a subset. Tannins in water can cause a faint yellow to dark brown color and may impart a musty odor but are considered an aesthetic water quality issue rather than a human health concern (WSC, 2008). As such, there is no regulatory guidance or numeric criteria for tannins in surface water. However, wood leachate can be toxic to aquatic life, and this toxicity is due to a variety of compounds and parameters, including tannins, lignins, terpenes, low $\mathrm{pH}$, and high oxygen demand (Hedmark and Scholz, 2008; Tao et al., 2005). Wood leachate is a complex matrix with toxicity that can be caused by a single compound, a variety of compounds, or even the interaction between compounds and water quality parameters (e.g., elevated organics in leachate lead to low dissolved oxygen, which can be toxic).

Oak wood (genus Quercus) has a relatively high tannin content; in fact, the word "tannin" comes from an early German word meaning oak (tanna; USFS, 2020). The extensive presence of a variety of oak species across the U.S. Midwest (Schoon, 1993; USFS, 2002) makes oak a desirable and costeffective candidate for denitrifying bioreactor fill. The USDA Natural Resources Conservation Service (USDANRCS) maintains a Conservation Practice Standard with criteria for the design of denitrifying bioreactors (USDA, 2015). The NRCS standard restricts the use of oak woodchips because of potential negative effects related to tannins, both on the denitrifying bacteria within the bioreactor and on downstream aquatic organisms. The national-level practice standard precludes any use of oak woodchips (USDA, 2015). The Illinois NRCS was granted a variance from the national standard to allow up to $50 \%$ of the woodchips in a bioreactor to be oak (USDA, 2017). Woodchip leachate has been studied in the context of runoff from sawmill waste piles (e.g., Hedmark and Scholz, 2008; Rex et al., 2016), but there have been no evaluations of denitrifying woodchip bioreactor tannin (or tannic acid) leaching, especially for oak woodchips.

The primary objective of this study was to assess the suitability of oak woodchips as a medium for denitrifying bioreactors with respect to their leaching of tannic acid and other parameters, such as true color and chemical oxygen demand (COD), which are important wastewater parameters that could provide context for woodchip leachate. This work explored (1) if oak leachate was significantly different from that of other types of bioreactor media and (2) the relative total nitrogen (TN) removal in the early leachate, considering both leached and removed N. This work was not intended to assess whether the leachate from a bioreactor poses an aquatic toxicity concern, but that is a suggested next step to build on this complementary lab and field study.

\section{Methods ANd Materials \\ LABORATORY LEACHING TESTS}

Nine rectangular Plexiglas denitrifying bioreactors (15 $\mathrm{cm} \times 15 \mathrm{~cm} \times 20 \mathrm{~cm}$; fig. 1 ) were constructed and operated in the Department of Agricultural and Biological Engineering Hydraulics Laboratory at the University of Illinois at Urbana-Champaign to test the leachate characteristics of woodchips, with an emphasis on leaching of tannic acid

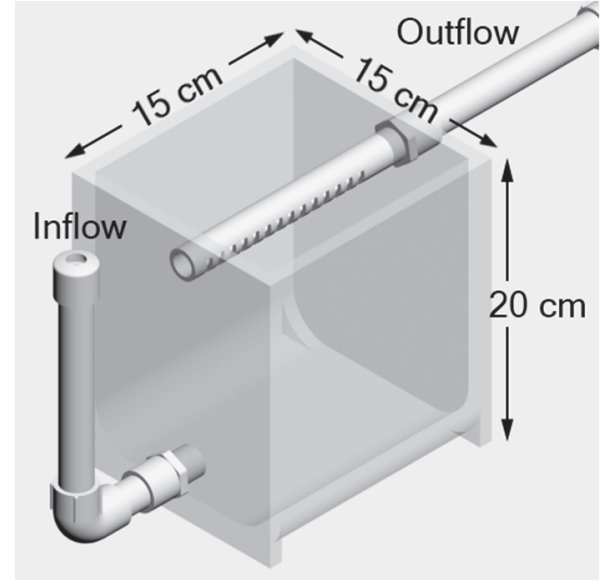

Figure 1. Diagram of upflow bioreactor used in lab leaching tests.

from an oak species. The bioreactors were packed in triplicate $(n=3)$ with one of three wood treatments: oak (Quercus rubra), ash (Fraxinus spp. L.), or a hardwood blend of commercial woodchips, termed "mixed hardwood" here. The oak chips were obtained from University of Illinois Facilities and Services staff, while the ash branches were collected from the University of Illinois Forestry Plantation in Urbana, Illinois, in November 2017 following an earlier emerald ash borer infestation. The hardwood blend was purchased from a commercial sawmill (Smithfield, Ill.).

The three wood media were chipped to create similar chip shapes and sizes using a residential chipper (Earthquake Tazz 3-inch $212 \mathrm{cc}$ gas wood chipper) and then sieved to the 6.3 to $19 \mathrm{~mm}$ particle size range to normalize potential particle size differences. The bioreactors were packed with this particle size range following ASTM methods (ASTM, 2012), i.e., a rammer was dropped from $45 \mathrm{~cm}$, and 50 blows were applied per woodchip layer. Each bioreactor was weighed at the time of packing, and the woodchip mass was later corrected for moisture content (subsets of woodchips were dried to a constant weight at $70^{\circ} \mathrm{C}$ starting on the day of bioreactor packing). Total porosities of the oak, ash, and mixed hardwood chips in the 6.3 to $19 \mathrm{~mm}$ particle size range were $61 \%$ to $63 \%$, respectively, which were not statistically different from each other (one-way analysis of variance, $p=0.148$; drainable porosities of $60 \%$ to $62 \%$, respectively; table 1). The median particle diameters $\left(\mathrm{D}_{50}\right)$ of the three sorted treatments differed statistically (15.3 to 16.8 $\mathrm{mm}$, respectively; $\mathrm{p}<0.001$; table 1 ) but were considered notably similar in practical applications of bioreactors. The bulk densities of the three media ranged from 263 to $300 \mathrm{~kg}$ $\mathrm{m}^{-3}$ (table 1 ; mixed hardwood was significantly greater than the others, $p=0.008$ ), and pore volumes ranged from 2.54 to $2.62 \mathrm{~L}$. Nutrient content of the wood media was analyzed using a wet digestion method (table 1; Brookside Laboratory, New Bremen, Ohio).

Each packed bioreactor cell continuously received drainage water collected twice weekly from a runoff pond at the University of Illinois Agricultural Engineering Farm (Urbana, Ill.). The collected water was dosed with potassium nitrate $\left(\mathrm{KNO}_{3}\right)$ to a concentration of $30.0 \pm 5.0 \mathrm{mg} \mathrm{NO} \mathrm{NO} \mathrm{L}^{-1}$ (mean $\pm \mathrm{SD}$; Masterflex L/S variable-speed drive pump, Vernon Hills, Ill.) to simulate water chemistries typical of 
Table 1. Physical and chemical properties of the oak, ash, and mixed hardwood chips used in lab leaching tests and of the woodchips used in five field bioreactors in Illinois $\left(C=\right.$ carbon, $N=$ nitrogen, $P=$ phosphorus, $D_{10}$ and $D_{50}=$ screen sizes through which $10 \%$ and $50 \%$, respectively, of the material by mass passed, and $\mathrm{UC}=$ uniformity coefficient, an indication of gradation of the woodchips, $\left.\mathrm{D}_{60} / \mathrm{D}_{10}\right)$. Means and standard deviations are of individual triplicate measurements.

\begin{tabular}{|c|c|c|c|c|c|c|c|c|c|c|}
\hline \multirow[b]{2}{*}{ Bioreactor } & \multirow{2}{*}{$\begin{array}{c}\text { Drainable } \\
\text { Porosity } \\
(\%)\end{array}$} & \multirow{2}{*}{$\begin{array}{c}\text { Total } \\
\text { Porosity } \\
(\%)\end{array}$} & \multirow{2}{*}{$\begin{array}{c}\text { Bulk } \\
\text { Density } \\
\left(\mathrm{kg} \mathrm{m}^{-3}\right)\end{array}$} & \multirow[b]{2}{*}{$\begin{array}{c}\mathrm{C} \\
(\%) \\
\end{array}$} & \multirow[b]{2}{*}{$\begin{array}{c}\mathrm{N} \\
(\%)\end{array}$} & \multirow[b]{2}{*}{$\begin{array}{c}\mathrm{P} \\
(\%)\end{array}$} & \multirow[b]{2}{*}{$\begin{array}{c}\mathrm{C}: \mathrm{N} \\
\text { Ratio }\end{array}$} & \multicolumn{3}{|c|}{ Particle Size } \\
\hline & & & & & & & & $\begin{array}{c}\mathrm{D}_{10} \\
(\mathrm{~mm})\end{array}$ & $\begin{array}{c}\mathrm{D}_{50} \\
(\mathrm{~mm})\end{array}$ & $\mathrm{UC}$ \\
\hline \multicolumn{11}{|l|}{ Lab leaching tests } \\
\hline Oak chips & $62 \pm 0.54$ & $63 \pm 0.74$ & $269 \pm 1.0$ & $47.2 \pm 0.1$ & $0.26 \pm 0.06$ & $0.03 \pm 0.004$ & $221 \pm 28$ & 9.1 & 15.3 & 1.8 \\
\hline Ash chips & $61 \pm 1.1$ & $63 \pm 1.1$ & $263 \pm 15$ & $47.3 \pm 0.3$ & $0.46 \pm 0.05$ & $0.05 \pm 0.006$ & $149 \pm 76$ & 9.8 & 15.8 & 1.7 \\
\hline Mixed hardwood & $60 \pm 0.3$ & $61 \pm 1.4$ & $300 \pm 7.8$ & $47.4 \pm 0.2$ & $0.21 \pm 0.01$ & $0.01 \pm 0.002$ & $227 \pm 17$ & 10.5 & 16.8 & 1.7 \\
\hline \multicolumn{11}{|l|}{ Field sites } \\
\hline UIUC Dudley Smith Farm & $65 \pm 0.8$ & $74 \pm 0.9$ & $214 \pm 1.6$ & $48.3 \pm 0.3$ & $0.16 \pm 0.02$ & $0.01 \pm 0.003$ & $299 \pm 42$ & 7.6 & 14.9 & 2.0 \\
\hline Henry County Farm Bureau & $62 \pm 2.8$ & $72 \pm 1.8$ & $199 \pm 10$ & $48.3 \pm 0.02$ & $0.23 \pm 0.08$ & $0.02 \pm 0.007$ & $235 \pm 96$ & 9.3 & 16.3 & 1.9 \\
\hline UIUC Agric. Eng. Farm & $59 \pm 1.3$ & $67 \pm 1.5$ & $227 \pm 14$ & $46.7 \pm 1.8$ & $0.59 \pm 0.13$ & $0.05 \pm 0.02$ & $127 \pm 96$ & 4.5 & 11.7 & 3.1 \\
\hline Bureau County Farm Bureau & $60 \pm 0.3$ & $69 \pm 1.3$ & $202 \pm 3.9$ & $45.0 \pm 1.2$ & $0.39 \pm 0.28$ & $0.04 \pm 0.02$ & $169 \pm 93$ & 5.2 & 13.2 & 2.9 \\
\hline Livingston County & $64 \pm 1.2$ & $68 \pm 1.1$ & $227 \pm 8.0$ & $47.8 \pm 0.4$ & $0.30 \pm 0.05$ & $0.01 \pm 0.001$ & $176 \pm 55$ & 2.9 & 5.0 & 2.1 \\
\hline
\end{tabular}

bioreactor field conditions. The upflow cells were operated at a hydraulic retention time (HRT) of $7.6 \pm 0.9 \mathrm{~h}$ (mean $\pm \mathrm{SD}$; flow rate $=0.38 \pm 0.03 \mathrm{~L} \mathrm{~h}^{-1}$ ) for 84 days, equating to 252 to 277 cumulative pore volumes of water treated. An approximately $8 \mathrm{~h}$ retention time was selected based on the HRTs used in previous laboratory leaching experiments (Hoover et al., 2016), which were within the same order of magnitude as the HRTs reported for field bioreactors, e.g., 0.5 to $2.8 \mathrm{~h}$ (Woli et al., 2010) and 0 to $48 \mathrm{~h}$ (Pluer et al., 2019). Each bioreactor's outlet flow rate was measured using a graduated cylinder and a stopwatch twice daily for the first month and once daily afterward. The experiment was deemed to be concluded at 84 days based on the bioreactor outflow concentrations being consistently within $0.5 \mathrm{mg}$ tannic acid $\mathrm{L}^{-1}$ of the detection limit $\left(0.1 \mathrm{mg} \mathrm{L}^{-1}\right)$ and consecutive sampling dates resulting in concentrations within $0.5 \mathrm{mg}$ tannic acid $\mathrm{L}^{-1}$ of each other.

Outflow samples were initially collected at relatively high frequency to capture initial leaching characteristics, with the sample collection frequency decreasing over time. Samples were collected when each individual cell started flowing $(t=-1 \mathrm{~h})$; when the last cell started flowing $(t=0$ h); at $t=1,2,4,8,12,24$, and $34 \mathrm{~h}$; at $t=2,3,5,7,9,12$, 14,17 , and $21 \mathrm{~d}$; and approximately weekly thereafter. The samples were collected into $100 \mathrm{~mL}$ high-density polyethylene bottles, filtered within $48 \mathrm{~h}$, and stored frozen until analysis. The samples were analyzed for tannic acid within a week of collection, while true color, COD, and TN analyses were performed nearly a year after sample collection once it was determined that they would provide important supplemental information for the tannic acid data. While this is beyond the suggested hold time ( $48 \mathrm{~h}$ to $28 \mathrm{~d}$, even when frozen) for these analytes (APHA, 2012), it still allows relative comparisons to be made between the three treatments, as they all had the same hold time. Only a subset of samples were analyzed for COD and TN $(t=2 \mathrm{~h}, 12 \mathrm{~h}$, and 3, 12, 37, and $84 \mathrm{~d}$ ). Bioreactor cell inflow and outflow samples were analyzed for tannic acid using the tyrosine method (APHA Standard Method 5550; model DR3900 spectrophotometer, Hach, Loveland, Colo.), true color was analyzed using the platinum-cobalt (Pt-Co) standard method (APHA, 2012), COD was analyzed using Standard Method 5220D (Jirka and Carter, 1975), and TN was analyzed using the persulfate digestion method (D'Elia et al., 1977). Quality assurance followed industry standards, including internal standards, blanks, and duplicates.

\section{Field Sites ANd Methods}

Five denitrifying bioreactors in Illinois were selected for analysis of tannic acid and true color based on their range of ages, flow and drainage characteristics, and media (tables 1 and 2). The University of Illinois at Urbana-Champaign (UIUC) Dudley Smith Farm bioreactor was selected based on the availability of archived outflow samples dating to early 2017 (i.e., the oldest bioreactor available) and the relatively high cumulative flow volume treated $\left(>38,000 \mathrm{~m}^{3}\right)$. This experimental bioreactor was installed with baffles to help route flow (Dougherty, 2018). The Henry County Farm Bureau bioreactor was selected considering its relatively small volume $\left(16 \mathrm{~m}^{3}\right)$ and drainage area (3 ha) and the availability of archived outflow samples dating to late 2017. The UIUC Agricultural Engineering Farm, Bureau County Farm Bureau, and Livingston County bioreactors were selected mainly due to their relatively young ages (less than one year from installation) and relatively low media $\mathrm{C}: \mathrm{N}$ ratio $(\leq 176$; table 1). The Livingston County ditch-diversion bioreactor treated ditch drainage water via a diversion structure. This experimental bioreactor was installed with a length to width ratio of approximately $1: 2$, meaning that there was a different orientation from the rule-of-thumb design consideration

Table 2. Site descriptions of five denitrifying bioreactors in Illinois where woodchip tannic acid leaching was evaluated. The drainage area of the Livingston County bioreactor is the estimated surface drainage area for this ditch-diversion bioreactor, while the drainage areas of the other bioreactors are estimated subsurface drainage areas. Sampling events represent when a sample was collected from both the inflow and outflow.

\begin{tabular}{|c|c|c|c|c|c|c|}
\hline Bioreactor & $\begin{array}{l}\text { Location } \\
\text { in Illinois }\end{array}$ & $\begin{array}{c}\text { Installation } \\
\text { Date }\end{array}$ & $\begin{array}{l}\text { Drainage Area } \\
\text { (ha) }\end{array}$ & $\begin{array}{c}\text { Dimensions } \\
(\mathrm{L} \times \mathrm{W} \times \mathrm{D}, \mathrm{m})\end{array}$ & $\begin{array}{c}\text { Volume } \\
\left(\mathrm{m}^{3}\right)\end{array}$ & $\begin{array}{c}\text { Sampling } \\
\text { Events }\end{array}$ \\
\hline UIUC Dudley Smith Farm & Christian County & Oct. 2016 & 14 & $17 \times 11 \times 0.9$ & 164 & 25 \\
\hline Henry County Farm Bureau & Henry County & Sept. 2017 & 2.8 & $9.8 \times 1.8 \times 0.9$ & 16 & 16 \\
\hline UIUC Agric. Engineering Farm & Champaign County & July 2018 & 3.0 & $6.1 \times 1.2 \times 0.6$ & 4.5 & 14 \\
\hline Bureau County Farm Bureau & Bureau County & Aug. 2018 & 6.9 & $15 \times 3.7 \times 0.9$ & 51 & 13 \\
\hline Livingston County & Livingston County & Oct. 2018 & 343 & $4.6 \times 9.1 \times 0.6$ & 26 & 9 \\
\hline
\end{tabular}


of 4:1 (USDA, 2015). The Farm Bureau bioreactors were designed to the USDA-NRCS Conservation Practice Standard (USDA, 2015). Across all five sites, woodchip total porosities ranged from $67 \%$ to $74 \%, \mathrm{D}_{50}$ ranged from 5.0 to $16.3 \mathrm{~mm}$, and C:N ranged from 127 to 299 (table 1). Physical properties (porosities, bulk density, and particle size distribution) were measured using methods described by Dougherty (2018). Woodchip types were generally selected by contractors and few details were provided beyond the Henry and Bureau County bioreactors, which were filled with custom $100 \%$ maple (genus Acer) chips.

Bioreactor inflow and outflow samples were collected by hand or using autosamplers either daily or weekly depending on the study site objectives; this analysis was an added value for other research being performed at the sites. Samples were transported to the lab on ice and filtered within $48 \mathrm{~h}$. Archived samples that had been preserved with 18 molar sulfuric acid $\left(\mathrm{H}_{2} \mathrm{SO}_{4}\right)$ were used for post-hoc analysis of the older bioreactors (Dudley Smith Farm and Henry County bioreactors), while newly collected samples (i.e., the only preservation was freezing) were analyzed from the newer sites and as monitoring continued at all sites. All available samples from the UIUC Agricultural Engineering Farm, Bureau County, and Livingston County bioreactors and the initial sampling event for each month from the archived Dudley Smith Farm and Henry County bioreactor samples were analyzed for tannic acid and true color following the methods described above. The total number of sampling events for each bioreactor ranged from 9 to 25 (table 2) and included both an inflow and outflow sample (i.e., 18 to 50 total samples per site). The archived samples were tested for $\mathrm{SO}_{4}{ }^{2-}$ ion interference with the tannic acid and true color methods, and no interference was detected. Pressure transducers placed in the outlet control structure along with an appropriate weir equation for each structure size were used to calculate the flow rate and corresponding annual flow volume for each bioreactor. For the Dudley Smith Farm and Henry County sites, a broadcrested V-notch weir equation was provided by the manufacturer. The UIUC Agricultural Engineering Farm, Bureau County, and Livingston County sites used a sharpcrested V-notch weir equation from Christianson et al. (2019). Compound weir equations were used when necessary following Chun and Cooke (2008).

Stream samples from three agricultural locations (UIUC Agricultural Engineering Farm, a Livingston County farm, and a Knox County farm) were analyzed for tannic acid, true color, and COD to provide a relative comparison for the lab tests and field bioreactor samples. Samples were collected across 1-month (July 2019, $n=4$ ), 7-month (November 2018 to June 2019, $n=10$ ), and 12-month (March 2018 to March 2019, $n=10$ ) periods for the three sites, respectively. The UIUC Agricultural Engineering Farm stream and the Livingston County farm streams were located near the bioreactors of the same name (table 2), and samples were collected upstream of the bioreactor outlets. The bioreactor outflow-receiving stream was not accessible at some of the other sites, so the Knox County stream was selected due to existing stream sampling for an unrelated saturated buffer monitoring project.

\section{Statistical AnAlysis}

Student t-tests were used to compare outflow concentrations from oak versus each of the other two treatments at individual sampling events and assess when the oak was no longer statistically significantly different from each of the other treatments for a given analyte. The cumulative masses leached of tannic acid, COD, and TN normalized by woodchip dry weight were compared across all three lab test treatments using one-way analysis of variance (ANOVA) at a significance level of $\alpha=0.05$ (Shapiro-Wilk normality test; Brown-Forsythe equal variance test; SigmaPlot version 14.0). Kruskal-Wallis testing was used when the data were not normally distributed. Either a t-test or a Mann-Whitney rank-sum test (when normality failed) were used when comparing two treatment groups (e.g., bioreactor outflow vs. stream sample concentrations). Tannic acid and true color from the lab tests were related using linear regression and correlation coefficients $\left(\mathrm{R}^{2}\right)$. Field data are presented as case studies and contextual information, and thus few statistical analyses were performed.

\section{RESULTS AND DisCUSSION \\ LEACHATE ChEMISTRY IN LAB TESTS}

The initial mean tannic acid concentrations (from sampling events within the first $24 \mathrm{~h}$ ) of the oak leachate were as much as 13 times greater than the initial concentrations from the mixed hardwood and more than 6 times greater than the initial concentrations from the ash woodchips. Over the first $24 \mathrm{~h}$, the mean oak, ash, and mixed hardwood tannic acid outflows ranged from $213 \pm 7.6$ to $783 \pm 29$, from $42 \pm 7.6$ to $215 \pm 13$, and from $23 \pm 2.9$ to $67 \pm 5.8 \mathrm{mg}$ tannic acid $\mathrm{L}^{-1}$, respectively (fig. $2 \mathrm{a}$, samples prior to day 1 ). The tannic acid concentrations were significantly greater in the oak leachate than in the ash and mixed hardwood treatments until day 37 and day 51, respectively, at which points the mean concentrations were all $\leq 0.50 \mathrm{mg}$ tannic acid $\mathrm{L}^{-1}$ (Student's t-test, $\mathrm{p}$ $=0.251$ and 0.100 , respectively; fig. $2 \mathrm{a}$ ). These times correspond to $113 \pm 0.6$ and $161 \pm 4.8$ cumulative pore volumes treated, given the $7.6 \mathrm{~h}$ retention time (table 3 ). The mean cumulative masses of tannic acid released from the oak, ash, and mixed hardwood chips were 7.7, 2.8, and $0.9 \mathrm{mg}$ tannic acid $\mathrm{g}^{-1}$ dry woodchip weight, respectively, at the end of the 84-day experiment (252 to 277 cumulative pore volumes), with oak significantly higher than the other two treatments (table 4).

True color in the leachate mirrored the tannic acid, with oak leaching more color than the ash and mixed hardwood (fig. 2b). Over the first $24 \mathrm{~h}$, the mean oak, ash, and mixed hardwood true color ranged from 4,670 to 6,760, from 602 to 2,600 , and from 460 to 1,620 Pt-Co units, respectively (fig. 2b). In contrast, Svensson et al. (2014) reported that the true color in $24 \mathrm{~h}$ batch tests was 1,300 to 2,130 Pt-Co units for oak (Quercus robur), 330 to $440 \mathrm{Pt}-\mathrm{Co}$ units for maple (Acer platanoides), and 140 to $150 \mathrm{Pt}-\mathrm{Co}$ units for pine ( $\mathrm{Pi}$ nus sylvestris) at two different woodchip to liquid ratios in leaching tests. A 28-day static leaching test by Rex et al. (2016) showed that true color ranged from approximately 100 to generally less than 800 true color units for pine, 

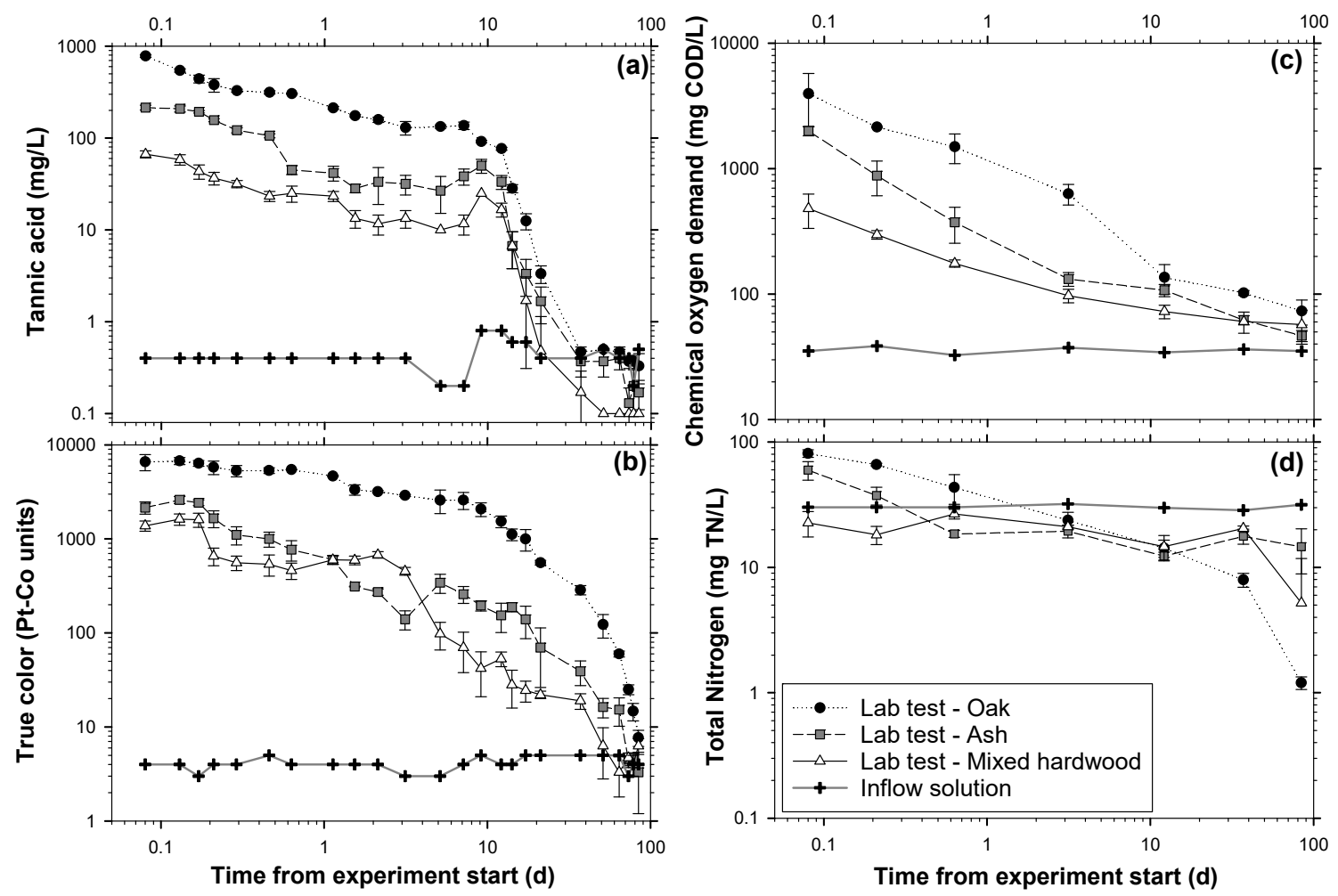

Figure 2. Means \pm standard deviations for (a) tannic acid, (b) true color, (c) chemical oxygen demand (COD), and (d) total nitrogen in the leachate of oak, ash, and mixed hardwood chips over an 84-day experiment ( $\sim 270$ cumulative pore volumes; $n=3)$. The inflow solution was runoff and drainage pond water mixed with potassium nitrate. To estimate pore volumes on the $x$-axis, multiply the day by approximately 3 .

Table 3. Mean cumulative pore volumes required for leachate of three wood types to meet each criterion for tannic acid, true color, and chemical oxygen demand (COD) in lab leaching tests. Outflow COD concentrations were never less than the stream mean.

\begin{tabular}{|c|c|c|c|c|c|c|c|c|}
\hline \multirow{3}{*}{ Treatment } & \multicolumn{2}{|c|}{ Tannic Acid } & \multicolumn{3}{|c|}{ True Color } & \multicolumn{3}{|c|}{ Chemical Oxygen Demand } \\
\hline & $\begin{array}{c}\text { No } \\
\text { Difference } \\
\text { between Oak } \\
\text { and Treatment }\end{array}$ & $\begin{array}{c}\text { Below } \\
\text { Stream } \\
\text { Mean of } \\
0.48 \mathrm{mg} \mathrm{L}^{-1} \\
\end{array}$ & $\begin{array}{c}\text { No } \\
\text { Difference } \\
\text { between Oak } \\
\text { and Treatment }\end{array}$ & $\begin{array}{c}\text { Below } \\
\text { Stream } \\
\text { Mean of } \\
35 \mathrm{Pt}-\mathrm{Co} \\
\end{array}$ & $\begin{array}{c}\text { Below USEPA } \\
\text { Drinking Water } \\
\text { Standard of } \\
15 \text { Pt-Co }\end{array}$ & $\begin{array}{c}\text { No } \\
\text { Difference } \\
\text { between Oak } \\
\text { and Treatment }\end{array}$ & $\begin{array}{c}\text { Below EU } \\
\text { Wastewater } \\
\text { Threshold of } \\
125 \mathrm{mg} \mathrm{L}^{-1}\end{array}$ & $\begin{array}{c}\text { Below } \\
\text { Stream } \\
\text { Mean of } \\
23 \mathrm{mg} \mathrm{L}^{-}\end{array}$ \\
\hline & \multicolumn{8}{|c|}{ Cumulative pore volume flushed through bioreactor to achieve the above criteria } \\
\hline Oak & - & $113 \pm 9.3$ & - & $228 \pm 12$ & $245 \pm 12$ & - & $113 \pm 9.3$ & \multirow{3}{*}{$\begin{array}{c}\text { Not } \\
\text { during } \\
\text { testing } \\
\text { for any } \\
\text { treatment }\end{array}$} \\
\hline Ash & $\begin{array}{c}113 \pm 0.6 \\
(p=0.251)\end{array}$ & $113 \pm 0.6$ & $\begin{array}{c}\text { Not during test } \\
(\mathrm{p}=0.044 \\
\text { at test end })\end{array}$ & $160 \pm 0.8$ & $231 \pm 1.6$ & $\begin{array}{c}267 \pm 1.2 \\
(p=0.055)\end{array}$ & $34 \pm 0.5$ & \\
\hline $\begin{array}{c}\text { Mixed } \\
\text { Hardwood }\end{array}$ & $\begin{array}{c}161 \pm 4.8 \\
(\mathrm{p}=0.100)\end{array}$ & $59 \pm 3.9$ & $\begin{array}{c}269 \pm 3.1 \\
(\mathrm{p}=0.294)\end{array}$ & $39 \pm 2.5$ & $161 \pm 4.4$ & $\begin{array}{c}269 \pm 3.1 \\
(\mathrm{p}=0.311)\end{array}$ & $8.5 \pm 0.5$ & \\
\hline
\end{tabular}

Table 4. Cumulative analyte mass normalized by woodchip dry weight at end of 84-day leaching experiment $(\sim 270$ cumulative pore volumes leached; $n=3$ ). Values are $\mathrm{mg} \mathrm{g}^{-1}$ dry woodchips. Means in each column followed by the same letter are not significantly different. Negative values for TN indicate net nitrogen removal rather than leaching.

\begin{tabular}{cccc}
\hline Treatment & Tannic Acid & COD & TN \\
\hline Oak & $7.7 \pm 1.3 \mathrm{a}$ & $34 \pm 9.9 \mathrm{a}$ & $-13 \pm 0.8$ \\
Ash & $2.8 \pm 0.4 \mathrm{~b}$ & $14 \pm 0.7 \mathrm{~b}$ & $-8.9 \pm 2.3$ \\
Mixed hardwood & $0.9 \pm 0.1 \mathrm{~b}$ & $12 \pm 6.6 \mathrm{~b}$ & $-10 \pm 2.1$ \\
\hline ANOVA & $\mathrm{p}<0.001$ & $\mathrm{p}=0.014$ & $\mathrm{p}=0.135$ \\
\hline
\end{tabular}

aspen, and spruce species (Pinus contorta Dougl., Populus tremuloides Michx., Picea engelmannii $\times$ glauca Parry, Picea mariana (Mill.) Britton). It is possible that the higher values in the current study were due to the flow-through rather than static testing, and the samples were analyzed for true color nearly a year after collection. Nevertheless, the earlier work corroborates that greater color can be leached from oak compared to other species.
The observed color of the three wood treatments decreased notably by the end of the second to third week (fig. 3). Correlating across the qualitative observed color and quantitative true color showed that a true color of generally about $20 \mathrm{Pt}-\mathrm{Co}$ units yielded a colorless solution; for example, the leachate from the mixed hardwood on day 21 in figure 3 averaged $22 \pm 2$ Pt-Co units across the three replicates. This aligns with the $15 \mathrm{Pt}-\mathrm{Co}$ color unit secondary standard for drinking water in the U.S. (USEPA, 2020). At the end of the experiment, the true color values were significantly higher for oak than for ash $(\mathrm{p}=0.044$; table 3 ; mean $\pm \mathrm{SD}=$ $7.7 \pm 1.5,3.3 \pm 2.1$, and $6.3 \pm 1.2 \mathrm{Pt}$-Co units for oak, ash, and mixed hardwood), but all were well under the $15 \mathrm{Pt}$-Co color unit secondary standard.

Although initial oak wood leachate is distinct from the initial leachate of other types of woods, leachate from the three types tested here generally became similar (i.e., tannic acid and COD) or below levels of concern (true color), 


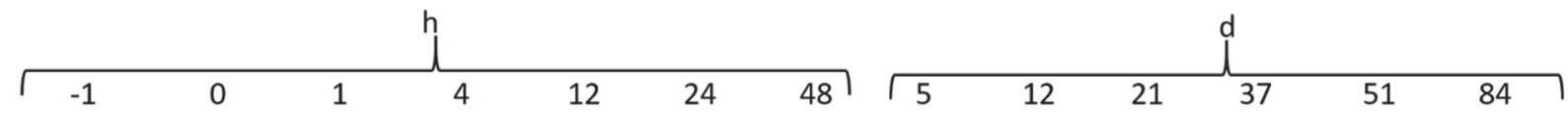

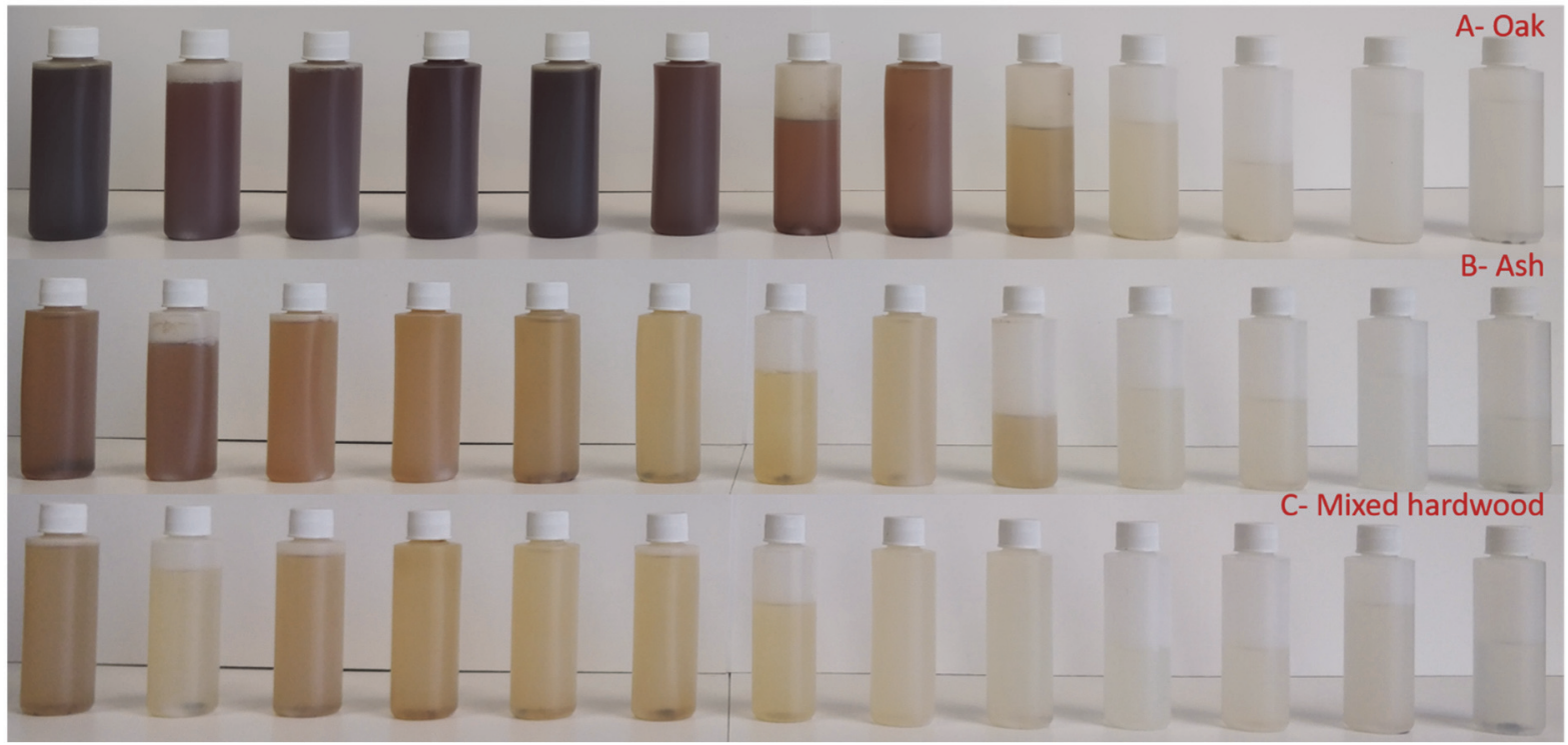

Figure 3. Apparent color of oak, ash, and mixed hardwood outflow samples from the lab leaching tests for a subset of sampling events; one replicate from each treatment is shown. Samples at $t=-1 \mathrm{~h}$ were collected when each individual cell started flowing; samples at $t=0 \mathrm{~h}$ were collected when the last cell started flowing ( $5 \mathrm{~h}$ after pump was turned on) and was considered the start of the test.

provided there was sufficient flushing (table 3 ). Assessing at what point these leachates are not an aquatic concern is difficult without toxicity testing. There is no threshold limit for tannic acid in water, so the true color of the leachate could be used as a guidance indicator given, of course, that other undesirable compounds may be present. While the USEPA threshold value for true color in drinking water is $15 \mathrm{Pt}-\mathrm{Co}$ units (USEPA, 2020), it could be argued that a drinking water standard should not be the goal for bioreactor outflows. Discrete samples from three Midwestern agricultural streams $(n=24)$ had concentrations of $0.48 \pm 0.13 \mathrm{mg}$ tannic acid $\mathrm{L}^{-1}$ (mean $\pm \mathrm{SD}$; range $=0.2$ to $0.7 \mathrm{mg}$ tannic acid $\mathrm{L}^{-1}$ ) and true color values averaging $35 \pm 14 \mathrm{Pt}-\mathrm{Co}$ units (range $=$ 20 to 54 Pt-Co units) (fig. 4a). The mean true color of the oak, ash, and mixed hardwood outflows were below this stream average by days 73,51 , and 14 , respectively $(228$,
160 , and 39 cumulative pore volumes, respectively; table 3 ). The final samples of the oak, ash, and hardwood leachates collected on day $84(n=9)$ had significantly lower tannic acid concentrations and true color values (both p-values $\leq$ 0.001 ) than the stream samples (fig. 4b).

A subset of the leaching test samples $(t=2 \mathrm{~h}, 12 \mathrm{~h}$, and 3 , 12,37 , and $84 \mathrm{~d}$ ) showed that the highest measured outflow COD concentrations for the oak, ash, and mixed hardwood chips were $3960 \pm 1790,2000 \pm 1670$, and $480 \pm 150 \mathrm{mg}$ COD $\mathrm{L}^{-1}$, respectively, meaning that the initial oak COD concentration was nearly 2 and 8 times greater than the ash and mixed hardwood concentrations, respectively (fig. 2c). For context, low, medium, and high strength wastewater has COD concentrations on the order of 250,430 , and $800 \mathrm{mg}$ COD L ${ }^{-1}$, respectively (Tchobanoglous et al., 2003). However, the water samples were not analyzed for COD until
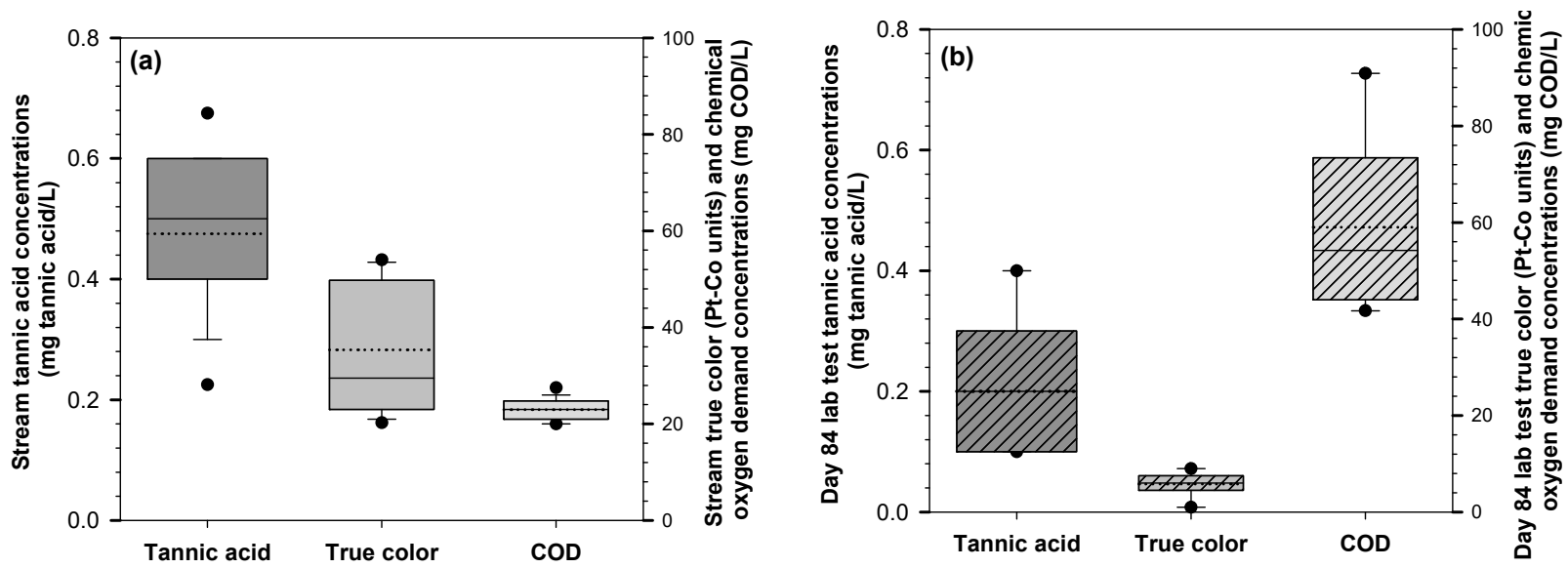

Figure 4. Ranges of tannic acid, true color, and chemical oxygen demand (COD) for (a) three streams in Illinois $(n=24)$ and $(b)$ across all wood treatments at day 84 in lab leaching tests $(n=9)$. Boxes, stems, and dots represent 25th and 75th, 10th and 90th, and 5th and 95th percentiles, respectively. Solid lines are medians, and dotted lines are means. Tannic acid is on the left axes; true color and COD are on the right axes. 
nearly one year after sample collection, so while absolute comparisons should not be made against reference values like this or other studies, relative comparisons can still be made between treatments. A review of wood leachate reported that COD concentrations generally range on the order of 100 to nearly $10,000 \mathrm{mg} \mathrm{COD} \mathrm{L}^{-1}$ (Hedmark and Scholz, 2008), with the notable exception of leaching from wood commonly known as cedar (Thuja plicata and Chamaecyparis nootkatensis), which can be $>14,000 \mathrm{mg} \mathrm{COD} \mathrm{L}^{-1}$ with $>3,000 \mathrm{mg}$ tannic acid L ${ }^{-1}$ (Tao et al., 2005). By the end of the experiment ( 84 days; approximately 270 cumulative pore volumes leached), the final outflow concentrations were 73 $\pm 17,47 \pm 4.7$, and $57 \pm 17 \mathrm{mg} \mathrm{COD} \mathrm{L}^{-1}$ for the oak, ash, and mixed hardwood treatments, respectively, and were not significantly different from each other (table 3 ). These values were still higher than the mean $\pm \mathrm{SD}$ for agricultural streams of $23 \pm 2.4 \mathrm{mg} \mathrm{COD} \mathrm{L}^{-1}$ (range $=20$ to $28 \mathrm{mg} \mathrm{COD} \mathrm{L}^{-1}$; fig. 4a vs. 4b) but lower than the European Union wastewater treatment plant discharge criterion of $125 \mathrm{mg}$ $\mathrm{COD} \mathrm{L}^{-1}$ (EU, 1991).

Christianson et al. (2016) reported that woodchip COD flushing in pilot-scale bioreactors treating aquaculture wastewater required between 45 and 80 cumulative pore volumes, although this could be as short as approximately 20 cumulative pore volumes depending on the retention time, wood type, and pollutant of concern (Healy et al., 2012). Von Ahnen et al. (2016) documented that initial outflow concentrations of $647 \mathrm{mg} \mathrm{COD} \mathrm{L}^{-1}$ from a willow (genus $\mathrm{Sa}$ lix) bioreactor were reduced by $90 \%$ after two days and were similar to the inflow concentrations within two weeks (estimated $\sim 15$ and $\sim 100$ cumulative pore volumes, respectively, based on a $12.5 \mathrm{~m}^{3}$ reactor and $2.5 \mathrm{~m}^{3} \mathrm{~h}^{-1}$ flow rate). These previously reported flushing pore volumes were less than the approximately 270 cumulative pore volumes found here to eliminate significant differences between oak and the other two woodchip types.

The oak woodchips initially eluted higher mean TN concentrations compared to the ash and mixed hardwood chips (fig. 2d). The pond supply water was dosed with $\mathrm{KNO}_{3}$ to achieve an inflow concentration of $30.0 \pm 5.0 \mathrm{mg} \mathrm{NO}_{3}-\mathrm{N} \mathrm{L}^{-1}$. This meant that overall $\mathrm{TN}$ concentration reductions were provided by day 3 by the oak woodchips and within $24 \mathrm{~h}$ by the ash and mixed hardwood chips (fig. 2d). There was no significant difference in mass-normalized TN removal between treatments over the course of the experiment $(p=$ 0.135 ; table 4 ), but the lower mean value for ash versus mixed hardwood and oak ( 8.9 vs. 10 and $13 \mathrm{mg}$ TN removed $\mathrm{g}^{-1}$ woodchip) might have been related to the ash treatment's notably lower C:N content (149 vs. 227 and 221; table 1). The lack of significant difference in TN removal by oak versus the other two wood types indicated the potential for biological $\mathrm{N}$ removal to be supported by this wood even given high concentrations of tannic acid; in other words, high concentrations of tannic acid presumably did not substantially alter the $\mathrm{N}$ removal capabilities of the bacteria. The TN concentrations that exceeded the inflow levels $\left(>50 \mathrm{mg} \mathrm{TN} \mathrm{L}^{-1}\right.$ for the oak and ash treatments) were likely due to leached $\mathrm{N}$.

\section{TANNIC ACID AND TRUe COLOR IN \\ FIELD BIOREACTOR OUTFLOW}

The five field bioreactors generally showed a trend of decreasing outflow tannic acid concentrations from their installation date (fig. 5). This was especially notable at the Henry County and Bureau County bioreactors, which decreased from maximums of 7.1 to 2.2 and from 2.4 to $0.4 \mathrm{mg}$ tannic acid $\mathrm{L}^{-1}$, respectively, across the analysis period $(69 \%$ and

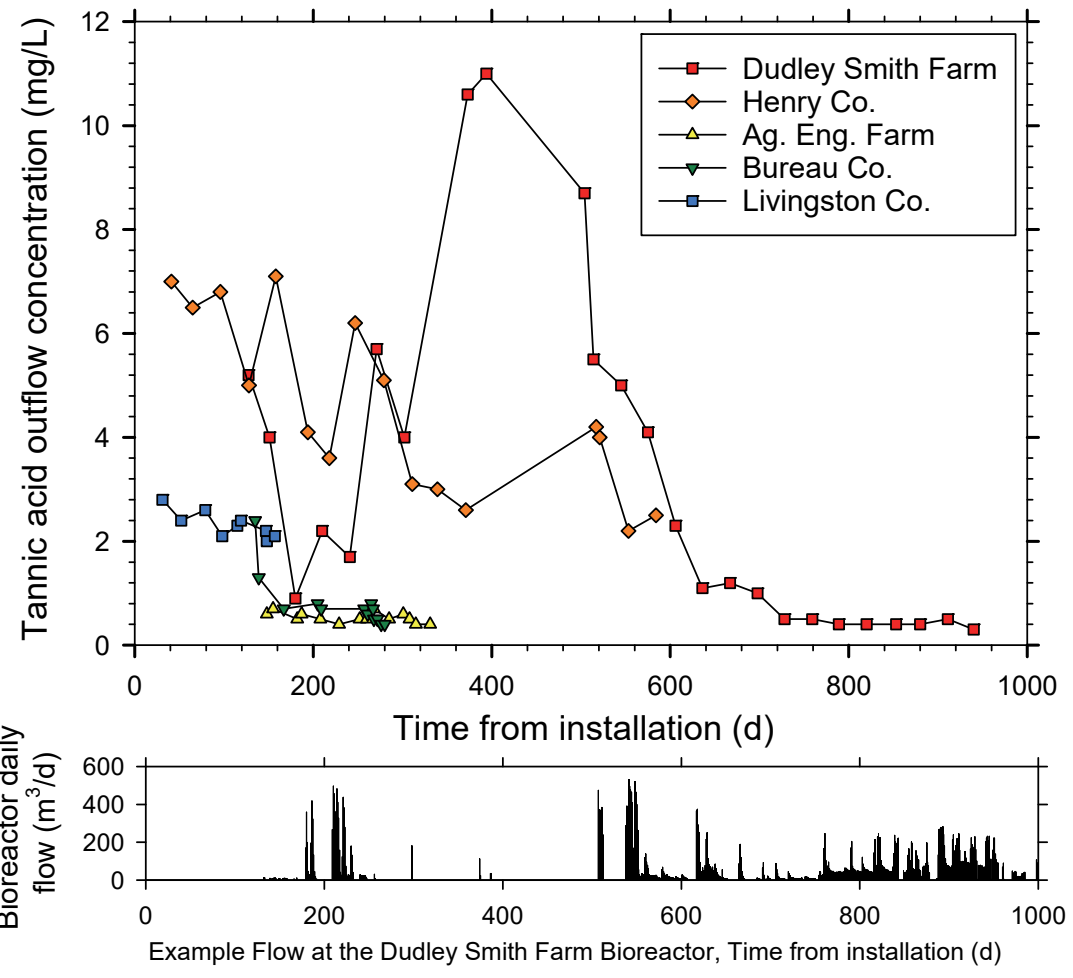

Figure 5. Tannic acid concentrations in field bioreactor outflow samples from five bioreactors in Illinois (top) and example bioreactor flow data for the Dudley Smith Farm bioreactor (bottom). 
$83 \%$ decreases over 395 and 141 days, respectively). These two bioreactors were filled with custom-ordered maple (genus Acer) woodchips (Xylem, Ltd., Story City, Iowa). Many of the field values were higher than the tannic acid concentrations observed toward the end of the 84-day lab experiment, especially considering the longer timeframe of the field study. For example, the mean outflows of all three lab treatments were $<0.5 \mathrm{mg}$ tannic acid $\mathrm{L}^{-1}$ by day 37 (113 cumulative pore volumes). These differences are likely due to the lab bioreactors being both consistently and fully saturated, while the field bioreactors experienced periods of wetting and drying (e.g., Maxwell et al., 2019) and likely had a layer of unsaturated chips near the top that might have leached during periods of rewetting. There were also sample storage differences for tannic acid analyses in that the lab test samples were analyzed for tannic acid within a week, while some of the archived samples from the field sites had been preserved. Nevertheless, the mass of leachable tannin contained in a woodchip is finite, and the lab tests provided insight using a controlled comparison between three defined treatments.

While initial (within one month of installation) outflow samples were not collected from the bioreactors, and those initial outflows would have contained the greatest tannic acid and color (e.g., figs. 2a and 2b), the highest measured tannic acid concentrations $\left(>10 \mathrm{mg}\right.$ tannic acid $\left.\mathrm{L}^{-1}\right)$ and true color values ( $>200$ Pt-Co units; not shown) were from the Dudley Smith Farm bioreactor when flow resumed following a dry period longer than two months in duration (fig. 5 top and bottom). These peak values subsided under flowing conditions. There was a corresponding increase in tannic acid in the bioreactor inflow to 4.4 to $8.1 \mathrm{mg}$ tannic acid $\mathrm{L}^{-1}$ during this time, which resulted in annual inflow means of 1.9 and $1.0 \mathrm{mg} \mathrm{L}^{-1}$ in 2017 and 2018, respectively (table 5). The increased tannic acid in the bioreactor inflow can explain some of the elevated concentrations in the outflow. It is possible for subsurface drainage water to have tannic acid present at levels greater than that of streams, which implies that there is processing of tannic acid in agricultural streams. The newness of the drainage system on the Dudley Smith Farm (installed in October 2016) combined with the dry period prior to those sampling events likely resulted in subsurface drainage (i.e., bioreactor inflow) tannic acid concentrations greater than the typical stream values.
Of the bioreactor outflow samples, $13 \%$ were lower than the mean stream tannic acid concentration, and $41 \%$ were lower than the true color values. Granted, this meant that the majority of samples were above the stream values, but the bioreactors were all less than three years old, which may have resulted in these percentages being relatively high compared to samples that would have been collected over an expected bioreactor life of 7 to 15 years. Annual mean bioreactor outflow at the Dudley Smith Farm decreased from 5.0 to 2.8 to $0.40 \mathrm{mg}$ tannic acid L $\mathrm{L}^{-1}$ and from 86 to 50 to $26 \mathrm{Pt}$ Co color units over the three annual periods (table 5), showing that leachate values decrease with time. This indicated the possibility of woodchip bioreactors eventually flushing at least these two analytes to ambient levels, as shown by the local stream data. Additional consideration for bioreactor outflows, such as the possibility of organic humic substances leading to the formation of disinfection byproducts if the downstream water is treated for drinking water, should also be considered (Abusallout and Hua, 2017).

The field bioreactors lost an estimated 0.03 to $43 \mathrm{mg}$ tannic acid $\mathrm{g}^{-1}$ dry woodchip over this monitoring period based on their constructed dimensions and estimated dry bulk densities (which accounts for moisture content). This encompassed the range of normalized leached mass in the lab leaching tests ( 0.9 to $7.7 \mathrm{mg}$ leached $\mathrm{g}^{-1}$ woodchip; table 4$)$. While these field evaluations likely did not capture the highest leaching period, corroboration between the lab and field assessments provides some insight on the range of leached tannic acid that could be expected ( 0.03 to $\sim 40 \mathrm{mg}$ tannic acid $\mathrm{g}^{-1}$ woodchip across this entire study), although the 84day lab experiment and the 1 to 3 year field study were of different durations.

\section{TANNIC ACID, True COLOR, ANd COD CORRELATIONS IN LEACHATE}

Wood-leached tannic acid and true color in the lab leaching tests were clearly correlated (fig. $6 \mathrm{~b}$; coefficient of determination $\left(\mathrm{R}^{2}\right)$ for oak, ash, and mixed hardwood $=0.85$, 0.95 , and 0.79 , respectively). However, very few lab test samples and none of the field samples (either bioreactor or stream) were below the $15 \mathrm{Pt}$-Co color unit secondary drinking water standard. Despite the relatively strong regression relationship, a low tannic acid concentration (e.g., $<1 \mathrm{mg}$ tannic acid $\mathrm{L}^{-1}$ ) did not necessarily mean that the true color would be less than 15 Pt-Co color units or even less than the

Table 5. Mean tannic acid and true color concentrations for the inflow and outflow of five bioreactors in Illinois by calendar year (11 site-years) along with the volume and pore volume of flow treated by year. There was insufficient flow for flow measurement in the control structure (but enough for sample collection) at the UIUC Agricultural Engineering Farm bioreactor between its installation in July 2018 and 31 December 2018.

\begin{tabular}{|c|c|c|c|c|c|c|c|}
\hline & \multirow{2}{*}{$\begin{array}{c}\text { Sampling } \\
\text { Events } \\
(n)\end{array}$} & \multicolumn{2}{|c|}{$\begin{array}{c}\text { Tannic Acid } \\
\left(\mathrm{mg} \mathrm{L}^{-1}\right)\end{array}$} & \multicolumn{2}{|c|}{$\begin{array}{l}\text { True Color } \\
\text { (Pt-Co units) }\end{array}$} & \multirow{2}{*}{$\begin{array}{c}\text { Water Volume } \\
\text { Treated } \\
\left(\mathrm{m}^{3} \text { year }^{-1}\right)\end{array}$} & \multirow{2}{*}{$\begin{array}{c}\text { No. of Pore } \\
\text { Volumes } \\
\text { Treated }\end{array}$} \\
\hline & & Inflow & Outflow & Inflow & Outflow & & \\
\hline UIUC Dudley Smith Farm (2017) & 9 & 1.9 & 5.0 & 4.8 & 86 & 7,890 & 65 \\
\hline UIUC Dudley Smith Farm (2018) & 11 & 1.0 & 2.8 & 5.1 & 50 & 15,800 & 130 \\
\hline UIUC Dudley Smith Farm (2019) & 5 & 0.4 & 0.40 & 4.6 & 25 & 14,800 & 120 \\
\hline Henry County Farm Bureau (2017) & 2 & 0.3 & 6.8 & 4.0 & 65 & 360 & 31 \\
\hline Henry County Farm Bureau (2018) & 10 & 0.2 & 4.7 & 5.2 & 51 & 16,200 & 1,400 \\
\hline Henry County Farm Bureau (2019) & 4 & 0.3 & 3.2 & 4.3 & 25 & 21,500 & 1,870 \\
\hline UIUC Agric. Eng. Farm (2018) & 2 & 0.5 & 0.7 & 43 & 62 & - & - \\
\hline UIUC Agric. Eng. Farm (2019) & 12 & 0.4 & 0.5 & 45 & 43 & 16,200 & 5,380 \\
\hline Bureau County Farm Bureau (2019) & 13 & 0.5 & 0.8 & 26 & 33 & 2,850 & 81 \\
\hline Livingston County (2018) & 2 & 0.7 & 2.6 & 47 & 91 & 1,510 & 86 \\
\hline Livingston County (2019) & 7 & 0.6 & 2.2 & 44 & 92 & 4,480 & 250 \\
\hline
\end{tabular}




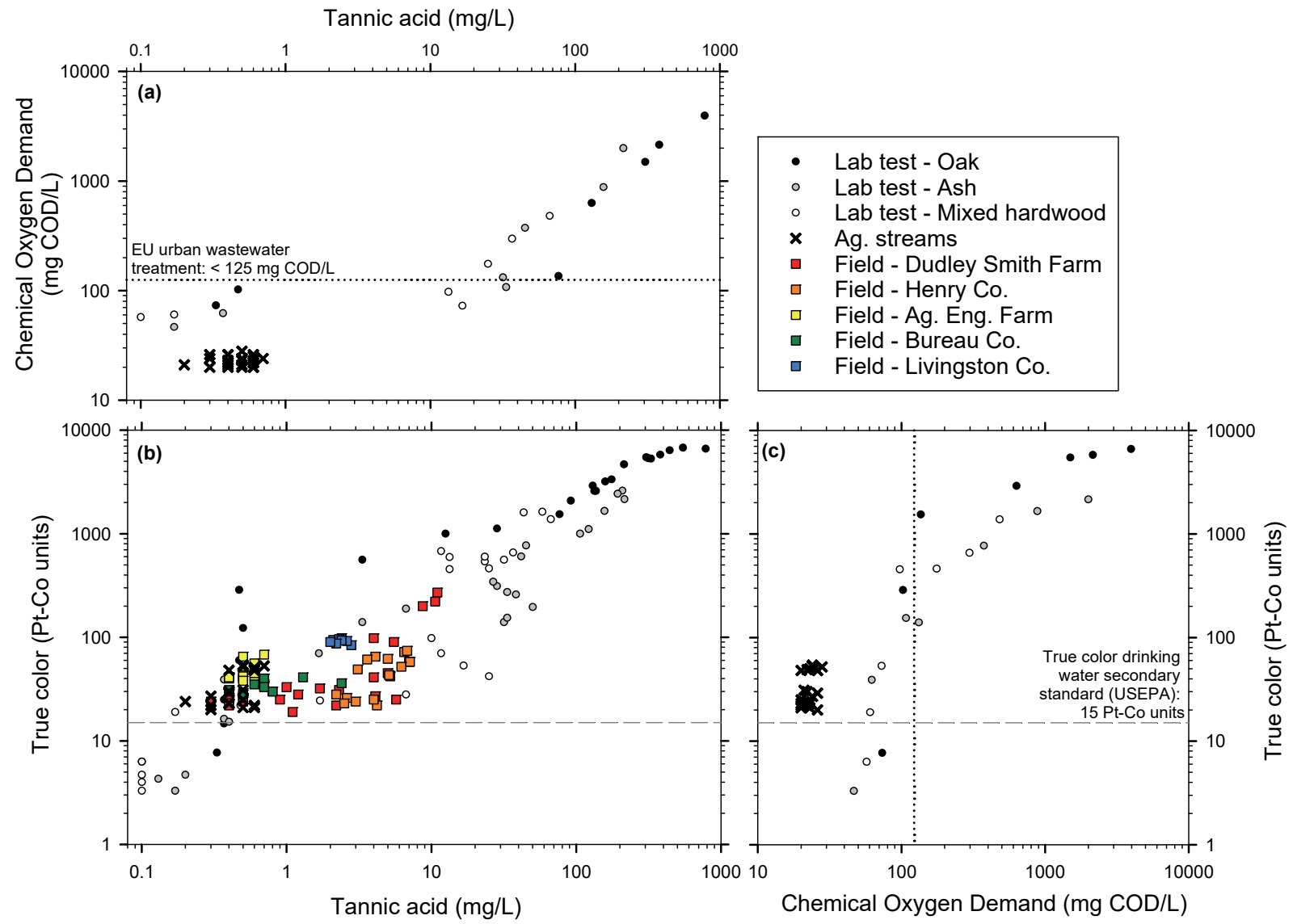

Figure 6. Relationships between (a) tannic acid and chemical oxygen demand (COD), (b) tannic acid and true color, and (c) COD and true color in lab leaching tests, field bioreactor outflows, and agricultural stream samples.

$35 \pm 14$ Pt-Co unit stream sample mean. Tannins and lignins (measured as tannic acid) may not be the only compounds that can affect wood leachate coloration.

Additional sources of color also became apparent when comparing stream and field bioreactor outflow samples. The field bioreactor outflows had a greater range of tannic acid concentrations than the streams, but that did not necessarily mean the field bioreactor outflows always had greater true color values (fig. 6 b; e.g., $41 \%$ of bioreactor outflow true color values were less than the stream average, see above). This provides a useful context for determining the "acceptability" of woodchip bioreactor outflows. While bioreactor initial outflows will be highly colored, and that color likely correlates with toxicity in undiluted forms, color may not be the best measure of outflow acceptability. In fact, Taylor and Carmichael (2003) stated that color "was nearly useless as an indicator of composition or toxicity of aspen leachate." It is well known that highly concentrated wood leachate can be toxic to aquatic life (Rex et al., 2016; Taylor et al., 1996; Woodhouse and Duff, 2004), but the potential toxicity of such leachate will vary based on a number of factors, including tree species, solid to liquid ratio of leaching (e.g., dilution, static vs. flow-through effects), and associated water chemistry (e.g., dissolved oxygen, $\mathrm{pH}$, alkalinity) (Hedmark and Scholz, 2008). Field bioreactor outflows showed a consistent trend of reduced tannic acid and true color over time, meaning that any potential toxicity issues related to these analytes would likely be an acute startup effect or recur after a drying and wetting cycle.

Tannic acid (fig. 6a) and true color (fig. 6c) were both positively correlated to COD in the lab leaching tests (treatment $\mathrm{R}^{2}$ values of 0.92 to 0.99 for tannic acid vs. COD and 0.80 to 0.93 for true color vs. COD) but less so for the stream samples $\left(\mathrm{R}^{2}\right.$ values of 0.00 for tannic acid vs. $\mathrm{COD}$ and 0.22 for true color vs. COD). Samples with COD concentrations less than the European Union wastewater discharge criterion of $125 \mathrm{mg} \mathrm{COD} \mathrm{L}^{-1}$ did not all meet the true color secondary drinking water standard; only three treatment mean values met both criteria (fig. 6c). Admittedly, these two criteria represent a mix of water comparison thresholds (wastewater, drinking water), but there are few water quality criteria relevant to non-regulated subsurface drainage and bioreactor outflows. Field bioreactor outflows were as high as nearly $12 \mathrm{mg}$ tannic acid $\mathrm{L}^{-1}$ which, based on the lab tests, may have resulted in COD concentrations of approximately the level of the European Union wastewater criterion indicated in figure 6 (extrapolating the field bioreactor data in fig. $6 \mathrm{a}$ to the COD values in fig. 6b). Many bioreactors will likely be consistent COD exporters (e.g., leaching test samples were never below the stream COD mean, table 3), although the differences between inflow and outflow COD concentrations are expected to decrease to over time. 


\section{CONCLUSIONS}

Oak woodchips leached significantly greater concentrations and woodchip-normalized masses of tannic acid and COD than ash and a mixed hardwood chips in the lab tests. However, the significant differences in leached concentrations between oak and the other wood treatments were eliminated, given a sufficient leaching period (tannic acid and COD: 161 and 269 cumulative pore volumes or 51 and 84 days, respectively). Moreover, relatively rapid TN removal (by day 3) by all treatments including oak indicated that the high tannic acid content in the leachate likely had no negative effect on N-removing bacteria (presumably denitrifiers). This provided evidence that the use of oak woodchips would not negatively impact the denitrifying performance of a bioreactor. Initial woodchip flushing of denitrifying bioreactors in the field is a well-documented phenomenon, which was shown here over a longer timeframe with decreases in average annual bioreactor outflow tannic acid and true color concentrations in 11 site-years of field bioreactor data. Measured field bioreactor outflow data did not exceed $12 \mathrm{mg}$ tannic acid $\mathrm{L}^{-1}$, although the first weeks of bioreactor flow were not captured.

While this was not an aquatic toxicity study, agricultural streams in the U.S. Midwest provided a context for both the lab and field results. Tannic acid concentrations and true color values from the oak, ash, and mixed hardwood chips eventually reached levels below the stream values, given sufficient flushing, which should increase confidence in this technology. The lab test COD concentrations always exceeded the stream values over the 84-day experiment, but this would be expected given the mode of action of denitrifying woodchip bioreactors (i.e., supplying carbon to fuel denitrification). True color did not appear to be the best parameter for estimating the tannin content of woodchip leachate due to discrepancies at low concentrations. From these results, potentially negative environmental and toxicity impacts would likely be startup issues, which could occur with many types of wood-based bioreactor media (e.g., the mixed hardwood tested here). The use of oak woodchips in bioreactors would provide the benefit of a readily available type of wood, which would reduce a barrier to implementation of this conservation practice. Toxicity testing, testing under drying and wetting conditions (as observed in the field), testing of bioreactor startup outflow remediation strategies, and further assessment of the effect of wood type on bioreactor performance are recommended next steps.

\section{ACKNOWLEDGEMENTS}

The authors acknowledge funding and support from USDA Hatch Project ILLU-802-925 and project NR185A12XXXXC004 CESU under the Great Rivers Umbrella Agreement 68-3A75-18-504 (USDA-NRCS). Thanks to Dr. Shiyang Li, who designed and constructed the laboratory bioreactor cells. The Illinois Nutrient Research and Education Council provided funding for installation and nutrient monitoring at three of the field sites, with additional funding from the University of Illinois College of ACES at the Dudley Smith Farm. A debt of gratitude is also owed to the Illinois Farm Bureau and their innovative and inspirational Bioreactor Partnership, which funded installation and monitoring at the two other field sites. Within this partnership, the Illinois NRCS is acknowledged for bioreactor design, and the Illinois Land Improvement Contractors Association is acknowledged for bioreactor construction.

\section{REFERENCES}

Abusallout, I., \& Hua, G. (2017). Characterization of dissolved organic carbon leached from a woodchip bioreactor. Chemosphere, 183, 36-43. https://doi.org/10.1016/j.chemosphere.2017.05.066

APHA. (2012). Collection and preservation of samples. In Standard methods for the examination of water and wastewater (22nd Ed.). Washington, DC: American Public Health Association.

ASTM. (2012). D1557-12: Standard test methods for laboratory compaction characteristics of soil using modified effort $(56,000$ $\left.\mathrm{ft}-\mathrm{lbf} / \mathrm{ft}^{3}\left(2,700 \mathrm{kN}-\mathrm{m} / \mathrm{m}^{3}\right)\right)$. West Consohocken, PA: ASTM.

Christianson, L. E., Bhandari, A., \& Helmers, M. J. (2012). A practice-oriented review of woodchip bioreactors for subsurface agricultural drainage. Appl. Eng. Agric., 28(6), 861-874. https://doi.org/10.13031/2013.42479

Christianson, L. E., Christianson, R. D., Lipka, A. E., Bailey, S., Chandrasoma, J., McCoy, C., ... Cooke, R. A. (2019). Calibration of stainless steel-edged V-notch weir stop logs for water level control structures. Appl. Eng. Agric., 35(5), 745-749. https://doi.org/10.13031/aea.13350

Christianson, L. E., Lepine, C., Sharrer, K. L., \& Summerfelt, S. T. (2016). Denitrifying bioreactor clogging potential during wastewater treatment. Water Res., 105, 147-156. https://doi.org/10.1016/j.watres.2016.08.067

Chun, J. A., \& Cooke, R. A. (2008). Technical note: Calibrating AgriDrain water level control structures using generalized weir and orifice equations. Appl. Eng. Agric., 24(5), 595-602. https://doi.org/10.13031/2013.25274

D'Elia, C. F., Steudler, P. A., \& Corwin, N. (1977). Determination of total nitrogen in aqueous samples using persulfate digestion. Limnol. Oceanogr., 22(4), 760-764. https://doi.org/10.4319/lo.1977.22.4.0760

Dougherty, H. (2018). Hydraulic evaluation of a denitrifying bioreactor with baffles. MS thesis. Urbana, IL: University of Illinois.

EU. (1991). Council Directive 91/271/EEC of 21 May 1991 concerning urban waste-water treatment. Brussels, Belgium: Council of the European Union. Retrieved from https://eurlex.europa.eu/legalcontent/EN/TXT/?uri=CELEX\%3A31991L0271

Fernández de Simón, B., Muiño, I., \& Cadahía, E. (2010). Characterization of volatile constituents in commercial oak wood chips. J. Agric. Food. Chem., 58(17), 9587-9596. https://doi.org/10.1021/jf101301a

Greenan, C. M., Moorman, T. B., Parkin, T. B., Kaspar, T. C., \& Jaynes, D. B. (2009). Denitrification in wood chip bioreactors at different water flows. J. Environ. Qual., 38(4), 1664-1671. https://doi.org/10.2134/jeq2008.0413

Healy, M. G., Ibrahim, T. G., Lanigan, G. J., Serrenho, A. J., \& Fenton, O. (2012). Nitrate removal rate, efficiency, and pollution swapping potential of different organic carbon media in laboratory denitrification bioreactors. Ecol. Eng., 40, 198-209. https://doi.org/10.1016/j.ecoleng.2011.12.010

Hedmark, A., \& Scholz, M. (2008). Review of environmental effects and treatment of runoff from storage and handling of wood. Bioresour. Tech., 99(14), 5997-6009. https://doi.org/10.1016/j.biortech.2007.12.042 
Hoover, N. L., Bhandari, A., Soupir, M. L., \& Moorman, T. B. (2016). Woodchip denitrification bioreactors: Impact of temperature and hydraulic retention time on nitrate removal. $J$. Environ. Qual., 45(3), 803-812. https://doi.org/10.2134/jeq2015.03.0161

Jirka, A. M., \& Carter, M. J. (1975). Micro semiautomated analysis of surface and waste waters for chemical oxygen demand. Anal. Chem., 47(8), 1397-1402. https://doi.org/10.1021/ac60358a004

Maxwell, B. M., Birgand, F., Schipper, L. A., Christianson, L. E., Tian, S., Helmers, M. J., ... Youssef, M. A. (2019). Dryingrewetting cycles affect nitrate removal rates in woodchip bioreactors. J. Environ. Qual., 48(1), 93-101. https://doi.org/10.2134/jeq2018.05.0199

Pluer, W. T., Morris, C. K., Walter, M. T., \& Geohring, L. D. (2019). Denitrifying bioreactor response during storm events. Agric. Water Mgmt., 213, 1109-1115. https://doi.org/10.1016/j.agwat.2018.12.004

Rex, J., Dubé, S., Krauskopf, P., \& Berch, S. (2016). Investigating potential toxicity of leachate from wood chip piles generated by roadside biomass operations. Forests, 7(2), article 40. https://doi.org/10.3390/f7020040

Schipper, L. A., Robertson, W. D., Gold, A. J., Jaynes, D. B., \& Cameron, S. C. (2010). Denitrifying bioreactors: An approach for reducing nitrate loads to receiving waters. Ecol. Eng., 36(11), 1532-1543. https://doi.org/10.1016/j.ecoleng.2010.04.008

Schoon, K. J. (1993). The Midwest urban tree index. J. Arboricult., 19(4), 230-237.

Svensson, H., Marques, M., Kaczala, F., \& Hogland, W. (2014). Leaching patterns from wood of different tree species and environmental implications related to wood storage areas. Water Environ. J., 28(2), 277-284. https://doi.org/10.1111/wej.12034

Tao, W., Hall, K. J., Masbough, A., Frankowski, K., \& Duff, S. J. B. (2005). Characterization of leachate from a woodwaste pile. Water Qual. Res. J., 40(4), 476-483. https://doi.org/10.2166/wqrj.2005.051

Taylor, B. R., \& Carmichael, N. B. (2003). Toxicity and chemistry of aspen wood leachate to aquatic life: Field study. Environ. Toxicol. Chem., 22(9), 2048-2056. https://doi.org/10.1897/02183

Taylor, B. R., Goudey, J. S., \& Carmichael, N. B. (1996). Toxicity of aspen wood leachate to aquatic life: Laboratory studies.
Environ. Toxicol. Chem., 15(2), 150-159.

https://doi.org/10.1002/etc.5620150213

Tchobanoglous, G., Burton, F. L., \& Stensel, H. D. (2003). Wastewater engineering: Treatment and reuse (4th Ed.). London, UK: McGraw-Hill.

USDA. (2015). Conservation practice standard: Denitrifying bioreactor, Code 605. Publication 605-CPS-1. Washington, DC: USDA Natural Resources Conservation Service.

USDA. (2017). Conservation practice standard: Denitrifying bioreactor, Code 605. Publication 605-CPS-1. Champaign, IL: USDA Natural Resources Conservation Service, Illinois.

USEPA. (2020). Secondary drinking water standards: Guidance for nuisance chemicals. Washington, DC: U.S. Environmental Protection Agency. Retrieved from https://www.epa.gov/dwstandardsregulations/secondarydrinking-water-standards-guidance-nuisance-chemicals

USFS. (2002). Current U.S. forest data and maps. Washington, DC: U.S. Forest Service. Retrieved from https://www.fia.fs.fed.us/slides/current-data.pdf

USFS. (2020). Tannins. Washington, DC: U.S. Forest Service. Retrieved from https://www.fs.fed.us/wildflowers/ethnobotany/tannins.shtml

von Ahnen, M., Pedersen, P. B., \& Dalsgaard, J. (2016). Start-up performance of a woodchip bioreactor operated end-of-pipe at a commercial fish farm: A case study. Aquacult. Eng., 74, 96-104. https://doi.org/10.1016/j.aquaeng.2016.07.002

Woli, K. P., David, M. B., Cooke, R. A., McIsaac, G. F., \& Mitchell, C. A. (2010). Nitrogen balance in and export from agricultural fields associated with controlled drainage systems and denitrifying bioreactors. Ecol. Eng., 36(11), 1558-1566. https://doi.org/10.1016/j.ecoleng.2010.04.024

Woodhouse, C., \& Duff, S. J. B. (2004). Treatment of log yard runoff in an aerobic trickling filter. Water Qual. Res. J., 39(3), 230-236. https://doi.org/10.2166/wqrj.2004.032

WSC. (2008). Tannins and groundwater. Washington, DC: Water Systems Council. Retrieved from https://www.watersystemscouncil.org/download/wellcare_infor mation_sheets/potential_groundwater_contaminant_information _sheets/96111501_Tannins.pdf 